\title{
Malaysian Teachers' Perspectives on Using Songs in English Language Teaching
}

\author{
Andrew Yau Hau Tse
}

\begin{abstract}
The employment of songs in an English classroom is not rare since it is the most invaluable tool to aid language acquisition, physical, and mental development. The objective of this research is to survey the perspectives of English as a Second Language (ESL) teachers $(n=60)$ in Malaysian state primary schools on using songs to teach English to young learners (YLs). Data collection is by means of questionnaires and the findings revealed that teachers have concrete conceptions on the teaching values of songs and its potency in teaching ESL to young children. Yet, the result depicted that teachers had difficulties in selecting songs and the recommendation is to provide them with interesting and enjoyable song materials for their classes. To conclude, songs can become useful sources to assist language learning and acquisition if teachers possess the strategies in using them.
\end{abstract}

Index Terms-Songs, language learning, language acquisition.

\section{INTRODUCTION}

"We don't cognise why songs are powerful, but from a personal angle they are", cited in Rosová, [1]. They can be conceived as an embedded sequence of work in the classroom so as to magnify their effects for the learners, especially young children. Ersöz [2] defines young learners in their first year of formal schooling, that is, 6 years old. Eurydice [3] claimed that the average starting age has dropped. Because of this, the syllabus design for the YL ESL classrooms has prospered.

If we scrutinize the English language syllabi design for YLs, we can discover that a) the focus is on communication; b) listening and speaking skills; and c) the inclusion of songs. Edelenbos et al. [4], for example, argued that games and songs had played an important role in EFL scenarios.

Why should we use songs in English language teaching? Salcedo [5] perceives songs as a melioration of memory of text and may be an effective way to provoke language acquisition. They also strengthen the grammatical structures learned in class, [5]. Lynch [6] pointed out that all children can undergo different types of accents. According to Reilley \& Ward [7], young children can imitate accents, intonation, and rhythm. Their pronunciation will greatly improve since they center on the sound, not meaning [7], [8].

Further, their cultural awareness will be developed. Music exists in different regions and environments, and it is a reflection of one's culture [9]. In short, songs can enhance children's language skills, linguistic knowledge,

Manuscript received September 22, 2013; revised November 28, 2013.

Andrew Yau Hau Tse is with the Universiti Tunku Abdul Rahman, Malaysia (e-mail: drdratse@gmail.com). pronunciation, and cultural consciousness.

\section{LITERATURE REVIEW}

Research also testifies the values of songs in an English class. Horn's [10] work signalled a positive improvement in listening skills among seventy-two second language (L2) students in a primary school in South Africa. The subjects were divided into two groups: control and experimental, with equal number of people.

First of all, a pre-test was executed on both groups. Music and motion were integrated in the programme for the experimental group within six months. Then the post-test was administered to two groups. The result demonstrated that both elements significantly help ESL learners in their language acquisition. Besides, their auditory and visual per-ception has developed. Another study by Horn [10] revealed that music could be adopted in class. Songs, to her, can be exploited as greetings, command training, vocabulary learning, as well as for relaxation and motivation purpose. Cognitive and physical skills can also be developed with a view to strengthening their power of ESL.

\section{METHODOLOGY}

\section{A. Research Questions and Hypotheses}

In Malaysia, English is reckoned as a second language (L2). Having reviewed the benefits of exploiting songs, the next move is to survey the views of Malaysian ESL primary teachers on its usage. Further, this research has three research questions:

1) What are Malaysian ESL teachers' convictions about the teaching values of employing songs in the class?

Hypothesis: Songs have fortified pedagogical benefits in teaching English to YLs since children love songs.

2) What are the Malaysian ESL teachers' dispositions towards using songs in teaching ESL to YLs?

Hypothesis: They have positive attitudes towards using songs since songs are the components of the English curriculum.

3) What are the perspectives of Malaysian ESL teachers on the efficacy of songs in the classroom?

Hypothesis: They have a positive view on this since songs pose a lot of benefits to children.

\section{B. Research Design}

This research is a descriptive study with an aim to surveying the beliefs, perspectives, and thoughts of Malaysian ESL teachers towards using songs in their YL ESL contexts. 


\section{Participants}

60 Malaysian ESL primary teachers from ten primary schools in Kuantan and Gambang took part in this research. Purposive sampling was adopted in choosing the subjects in order to obtain the most capable data.

\section{Research Instrument}

An English questionnaire was adopted and distributed to the primary teachers in Kuantan and Gambang, Malaysia. It comprises eighteen questions. In the questionnaire, participants are notified of the purpose of research and are requested to answer all questions on the questionnaire. In the end, they have to select the best option which represents their conception on using songs. The questionnaire uses a five-point Likert type scale.

With the aid of pertinent literature, 15 items were prepared. It turned out that the reliability co-efficient of the questionnaire was 0.672 , which is an indication of moderate reliability. Nevertheless, any figure above 0.67 is considered to be reliable [11].

\section{E. Data Analysis}

After collection of questionnaire answers, the next step was to use SPSS to analyse the data. Descriptive analysis is adopted to display the frequencies and percentages and this is reflected in the tables.

\section{RESULTS}

The results obtained from data analysis are presented is the demogra-phic information about the participants $(n=60)$.

It reveals teachers' views on the values of employing songs by means of five statements (Nos. 1-5). The first statement revealed that the majority of ESL teachers (90\%) trust that songs should be included in the English curriculum. The second statement indicated that ESL teachers (73.3\%) believe that songs provide YLs with a good opportunity to express their skills in many language areas.

Statement 3 showed that $88.3 \%$ of the respondents trust that songs are enjoyable and beneficial. Statement 4 depicted that $60 \%$ of ESL teachers disagree with this statement, that is, songs are used for fun and for breaking down monotony in the learning process. Finally, the results of statement 5 indicated that $90.2 \%$ of teachers perceive songs as important in promoting listening skills.

Overall, the findings echoes with previous research on pedagogical values, teaching curriculum, and vitality in developing listening skills in YL ESL study. In Table 3, teachers' orientation towards using songs is surveyed by means of five statements (Nos. 6-10). Statement 6 revealed that $68.4 \%$ of ESL teachers claim that they do not have ample resources. Statement 7 indicated that $66.6 \%$ of ESL teachers find it laborious to find proper songs for every topic in the English language curriculum. Statement 8 showed that the minority of ESL teachers $(41.7 \%)$ con-ceived songs as a distraction of students' attention during the lesson.

The results in Statement 9 depicted that more than three quarters of ESL teachers (76.7\%) disagreed that using songs in English classes is time consuming. Finally, Statement 10 showed that $40 \%$ of the ESL teachers voice their opinion that they cannot evaluate the learners' erudition of English when songs are being adopted. Overall, $68.4 \%$ of all respondents claim that there are inadequate song materials, and $66.6 \%$ find it arduous to find suitable songs for classroom use.

Finding relevant songs is the major concern of ESL teachers in these findings. The researcher of the present study has supplied some practical web-sites for the use of English teachers. These can be found at the end of this article. The rationale is to help teachers teach and to assist students learn English.

$41.7 \%$ of all respondents agreed that songs may deflect the learners' concentration. This result signals that about fifty percent of the respondents have difficulties on how to use songs for teaching purpose. However, results of Statement 9 showed that ESL teachers $(76.7 \%)$ believe that the use of songs in the class is not time wasting and therefore has fortified teachers' feelings in using them. In Table 4, five statements (Nos. 11-15) were used to research teachers' viewpoints on the efficacy of using songs in English teaching. Statement 11 indicated that $90 \%$ of ESL teachers declare that it can expedite the memorization of vocabulary.

In Statement 12, 83.3\% of ESL teachers state that the substantial repetition provided by songs leads to naturally use the target language. Statement 13 claimed that all teachers agree that songs can stimulate and amuse young learners. Statement 14 depicted that most teachers $(86.6 \%)$ disagree that songs are ineffective in English teaching. The final statement showed that $80 \%$ of teachers agree that songs can alleviate students' nervousness towards English learning.

Overall, we can reason that ESL teachers have a positive impact on the effective use of songs. Based on data analysis, we can postulate that songs are extremely actuating and interesting $(100 \%)$. Next, they produce a lot of repetition $(83.3 \%)$ and can reduce the learners' worries towards learning English (80\%).

\section{CONCLUSION AND RECOMMENDATIONS}

The purpose of this study is to probe the angles of Malaysian ESL primary teachers on the employment of songs. Specifically, it aims at inquiring their philosophy on the pedagogical value, attitudes, and cerebration on the impact of songs in English teaching. Based on appropriate literature, songs have proved to be the most impressive characteristics of ESL programmes, that they are helpful listening materials, and the most relaxing and language learning strategy reported by young learners of English. In addition, they are vital and indispensable elements of ESL learning and teaching in YL scenario.

If we scrutinize the Malaysian ESL syllabi for YLs, we discover that songs are given limited consideration, for instance, not many songs are incorporated in English textbooks. The researcher of this study believes that this should be adopted on a more structured and systematic manner in Malaysia.

For novice or inexperienced ESL teachers, a list of online websites is given below to help them select their songs to be used in the classroom. They should seek and exploit other relevant websites which they reckon as appropriate for their students. 
1) http://www.genkienglish.net/iamarobot.htm: This is a very useful website for primary English teachers and ESL learners. Videos, games, phonics, flashcards, as well as teaching tips on how to use songs in the classroom are given and discussed. All activities are enjoyable and entertaining.

2) http://www.youtube.com/watch?v=9aB1OIMAoYo\&fe ature=related: A website with 22 songs composed of pictures, words, and music. Primary students can learn English by singing. This is a good listening and speaking activity in/out of the classroom.

3) http://www.eslthemes.com/music/a_music_index.htm:

There are lots of children's songs, song activities, and lyrics for primary teachers to download. This website is ideal for primary ESL learners.

4) http://wn.com/Action_song_by_primary_students: This site contains many action songs sung by primary students in groups. Students move around as if they were acting in a play. They get a lot of fun in singing, moving, and acting.

To conclude, songs have provided students with a relaxed atmosphere and thus intuitively learn English, their target language. Further, these are enjoyable language learning activities and there-fore should be promoted in schools, especially young learners, since they can easily acquire the language. Teachers, the front-line educators, have to select appropriate songs for their students. It is hoped that this paper can help the primary English teachers in Malaysia to use songs strategically, confidently, and effectively in the classroom.

\section{REFERENCES}

[1] V. Rosová, "The use of music in teaching English,” A thesis, Masaryk University, Czech, 2007.

[2] A. Ersöz, Teaching English to Young Learners, Ankara: Kozan Ofset, 2007.
[3] Eurydice, Key Data on Teaching Languages at School in Europe, Brussels: Eurydice European Unit, 2005.

[4] P. Edelenbos, R. Johnstone, and A. Kubanek, The Main Pedagogical Prin-ciples Underlying the Teaching of Languages to Very Young Learners, European Commission, Education and Culture and Communication Multiling-ualism Policy, 2006.

[5] C. Salcedo, "The effects of songs in the foreign language classroom on text recall and involuntary mental rehearsal," A dissertation, Louisiana State University, Unpublished PhD thesis, 2002.

[6] L. Lynch. (2005). 9 reasons why you should use songs to teach English as a foreign language. [Online]. Available: http://ezinearticles.com/?9-Reasons-Why-You-Should-Use-Songs-toTeach-English-as-a-Foreign-Language $\&$ id $=104988$

[7] V. Reilley and S. Ward. (1997). Very young learners. Oxford: Cambridge University Press. [Online]. Available: http://www.iatef.org.pl/tdal/n9songs.htm.

[8] N. Klancar. (April 21, 2009). Developing speaking skills in the young learners' classroom. The Internet TESL Journal. [Online]. 12(11). Available: http://iteslj.org/Techniques/KalancarSpeakingSkills.htlm, 2006.

[9] T. Blodget, Teaching the Target Language through the Lyrics of Melodic Music, Musicapaedia, 2000.

[10] C. Horn. (May 8, 2009). English Second Language Learners: Using Music to Enhance the Listening Abilities of Grade Ones, A thesis, University of South Africa. [Online]. Available: http://etd.unisa.ac.za.ETD-db/theses/availble/etd09212007133117/unr estricted/disertation.pdf

[11] L. Cohen, L. Manion, and K. Morrison, Research Methods in Education, Routledge, 2007.

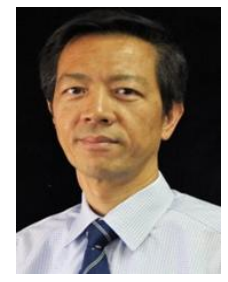

Andrew Tse earned a doctor of education degree in applied linguistics and TESOL from the University of Leicester, England. Currently he is an assistant professor of Linguistics at the Faculty of Arts and Social Science, Universiti Tunku Abdul Rahman (UTAR), Malaysia. Two books entitled 'Language Learning Strategies of Grades 7-8 Students in Hong Kong' and 'Inferencing- $A$ Vocabulary Comprehension Skill' were published in 2012 and 2013 respectively. His research interests include learning strategies, vocabulary, error analysis, discourse analysis, and sociolinguistics. Dr Tse is a member of MELTA, Malaysia and in May 2013 had won a bronze medal in a research project entitled 'Self-access English Language Learning Web-sites'. 